\title{
Redescription of cystacanths of Corynosoma pseudohamanni Zdzitowiecki, 1984 (Acanthocephala: Polymorphidae) from paratenic fish hosts
}

\author{
Šárka Mašová and Vlastimil Baruš
}

Department of Botany and Zoology, Faculty of Science, Masaryk University, Brno, Czech Republic

\begin{abstract}
Cystacanths of Corynosoma pseudohamanni Zdzitowiecki, 1984 (Palaeacanthocephala: Polymorphidae) are redescribed on the basis of specimens recovered from three species of Antarctic notothenioid fish, Trematomus bernacchii Boulenger, Gobionotothen gibberifrons (Lönnberg) and Notothenia coriiceps Richardson, collected from the Prince Gustav Channel, Antarctica. The cystacanths' morphometry and their internal anatomy including trunk muscles were studied using light and scanning electron microscopy (SEM). The characteristic features of this species such as the length of proboscis and the number of hooks (i.e. 260 hooks arranged in 20 rows with 13 hooks each, including two basal hooks) were confirmed and the intraspecific variability was evaluated. Sexual dimorphism was manifested in the shape of the hindtrunk, and the distribution and extent of the somatic armature only. SEM observations of internal anatomy revealed the detailed organization of trunk musculature.
\end{abstract}

Keywords: Acanthocephala, Corynosoma pseudohamanni, redescription, morphology, James Ross Island, Antarctica

Acanthocephalans are helminths with life cycles involving at least two hosts. Apart from intermediate and definitive hosts, their life cycle can also include paratenic hosts. Definitive hosts of Antarctic palaeacanthocephalan species include fishes, birds and marine mammals (Zdzitowiecki 1984a,b, 1986, 1996).

Corynosoma pseudohamanni Zdzitowiecki, 1984 was described by Zdzitowiecki (1984b) from the Weddell seal, Leptonychotes weddellii (Lesson) (type host), and four other species of seals in the environs of the South Shetland Islands, Antarctica. Acanthellae and cystacanths of this species in intermediate hosts (Amphipoda) from Antarctica were found by Hoberg (1986), Zdzitowiecki (2001), Zdzitowiecki and Presler (2001), and Laskowski et al. (2010). Fishes of the families Nototheniidae and Chaenichthyidae and less frequently also of the Bathydraconidae and Harpagiferidae serve as paratenic hosts of Corynosoma Lühe, 1904 species - Zdzitowiecki (1984b, 1986, 1990, 1996), Moser and Cowen (1991), Zdzitowiecki and Zadrożny (1999), Zdzitowiecki et al. (1999), Laskowski et al. (2008, 2012).

According to Zdzitowiecki (1986), the distribution of C. pseudohamanni cystacanths is probably circumpolar in Antarctica and the studies by Zdzitowiecki (1996) and Zdzitowiecki et al. (1999) confirm this assumption. The morphology of C. pseudohamanni cystacanths from intermediate hosts (amphipods) was described by Zdzitowiecki (2001) and Laskowski et al. (2010), whereas immature specimens from accidental hosts [seabirds $P y$ goscelis antarcticus (Forster) and Phalacrocorax atriceps King] by Dimitrova et al. (1996). However, morphometric data on cystacanths from paratenic fish hosts are incomplete.

The aims of this study were to redescribe $C$. pseudohamanni cystacanths and to provide detailed illustrations and scanning electron micrographs of the morphology and muscle anatomy of encysted juveniles in paratenic hosts. A further aim was to supplement current data with information about intraspecific variability.

\section{MATERIALS AND METHODS}

Field investigations were carried out from January to March 2012 during the Czech Antarctic expedition 2011-2012. In total, 15 specimens of five fish species were examined for parasites. They were caught with gill nets in the Prince Gustav Channel $\left(63^{\circ} 47^{\prime} 58^{\prime \prime} \mathrm{S}, 57^{\circ} 55^{\prime} 12^{\prime \prime} \mathrm{W}\right.$; depth about $\left.30 \mathrm{~m}\right)$, in front of the Johann Gregor Mendel station on the James Ross Island. Examinations of fresh fish were carried out using a dissecting microscope. Among other parasites, acanthocephalan cystacanths of the species Corynosoma pseudohamanni were collected from three Trematomus bernacchii Boulenger, five Gobionotothen gibberifrons (Lönnberg) and one Notothenia coriiceps Richardson. Five Trematomus eulepidotus Regan and one T. newnesi Boulenger were not infected. Encapsulated acanthocephalans were present on the surfaces of viscera and on the mesenteries. Some cystacanths were liberated from cysts using entomological needles. They were collected live, then washed and relaxed 

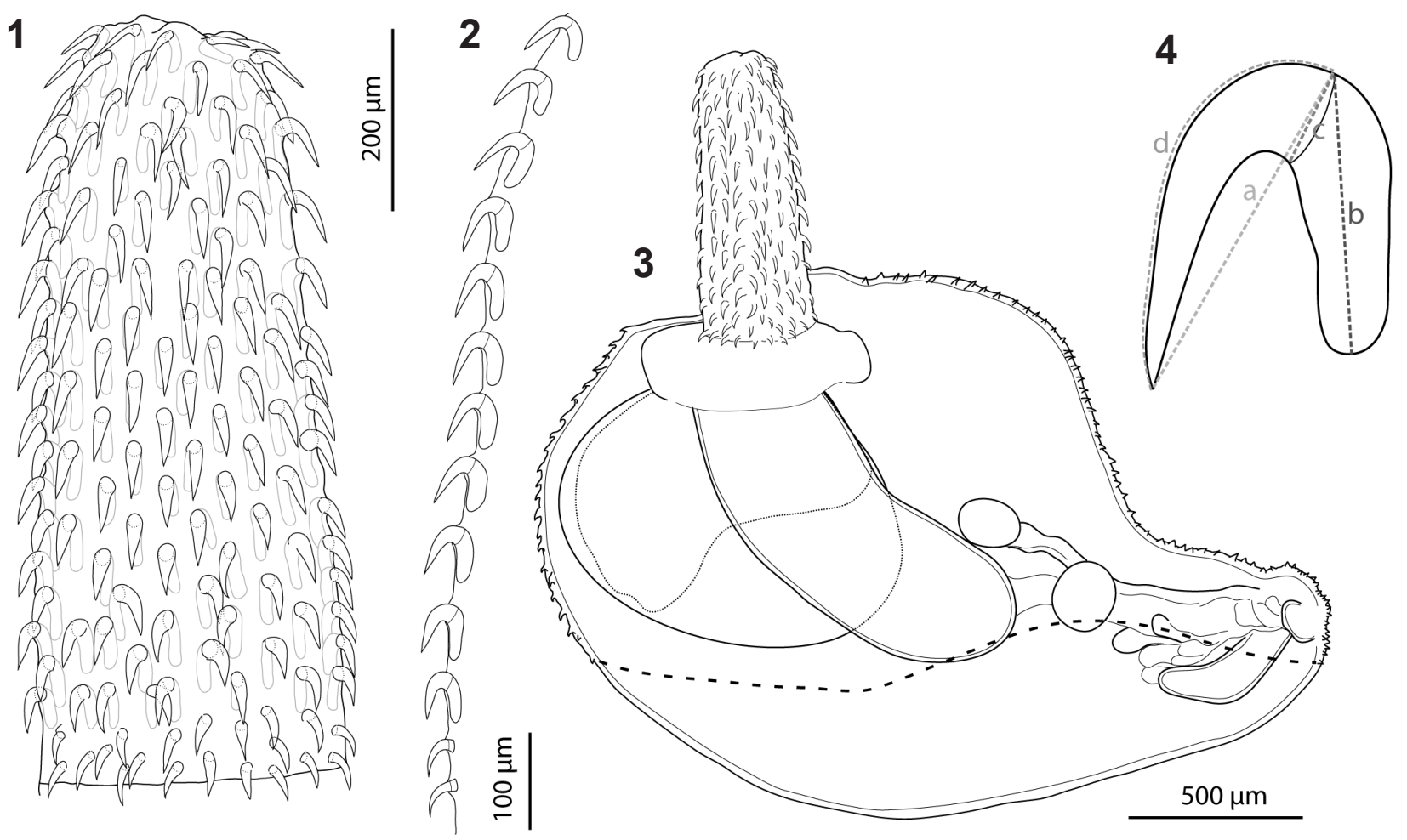

Figs. 1-4. Male specimen of a cystacanth of Corynosoma pseudohamanni Zdzitowiecki, 1984 from Trematomus bernacchii, Weddell Sea. Line drawings. Fig. 1. Proboscis. Fig. 2. Lateral row of proboscis hooks showing roots. Fig. 3. Lateral view of specimen with internal organs and anlagen of testes. Outline showing the range of trunk spines (dashed line). Fig. 4. Profile of proboscis hook illustrating the method of measuring the following characters: thorn length (a), root length (b), base width (c), and length of curvature of the blade (d).

several minutes in saline solution, and fixed immediately in hot $4 \%$ formaldehyde solution.

For morphological and morphometrical observations, five males and six females of relaxed specimens with everted or partially everted proboscises were cleared with glycerine and then studied using temporary whole-mounts in glycerine. Light microscopic observations were made with an Olympus BX51 microscope equipped with differential interference contrast (DIC) optics, a digital image analysis system (Motion Stream, Olympus), and a drawing tube attachment. Measurements of hooks were made according to Fig. 4; the curvature of the thorn blade was measured by tracing method. The autofluorescence of acanthocephalans was viewed and documented using an Olympus IX81 microscope equipped with a FluoView 500 laser scanning confocal unit (Olympus FluoView Ver.4.3 software), using filters with excitation in the range $475-490 \mathrm{~nm}$ and emission in the range 505-535 nm. Analysis was performed using Olympus FluoView Ver.1.7a Viewer software.

To study structural details of external morphology and internal anatomy, scanning electron microscopy (SEM) was used. Fixed specimens ( $4 \%$ formaldehyde solution) - two relaxed and four encysted cystacanths cut in halves - were postfixed in $1 \% \mathrm{OsO}_{4}$ for $1 \mathrm{~h}$ (in phosphate buffer), dehydrated through a graded acetone series, critical-point dried (in a Pelco CPD 2 critical point dryer) using liquid $\mathrm{CO}_{2}$, mounted on aluminium stubs with a double-sided adhesive disc, and sputter-coated with gold (in a Polaron Equipment LTD SEM Coating unit E5100). The samples were examined using a JEOL JSM-7401F FE SEM at an accelerating voltage of $4 \mathrm{kV}$.
Fish names follow FishBase (Froese and Pauly 2012), amphipod names the World Register of Marine Species (Appeltans et al. 2012). Muscle terminology follows Aznar et al. (1999, 2006). Measurements are given in micrometres $(\mu \mathrm{m})$ with the means in parentheses unless otherwise indicated.

\section{RESULTS}

Family Polymorphidae Meyer, 1931

Corynosoma pseudohamanni Zdzitowiecki, 1984

cystacanths

Figs. 1-17

Previous erroneous identification: $C$. hamanni of various authors nec Linstow (1892) pro parte; C. antarcticum sensu Johnston and Best (1937) nec Rennie (1906) pro parte (for a survey see Zdzitowiecki 1984b, 1986, Zdzitowiecki et al. 1999).

Description (based on 11 relaxed specimens with evaginated or partly evaginated proboscis, and on four encysted cystacanths from the body cavity): Males and females similar in size and shape. Proboscis cylindrical (Fig. 1), with retractor muscle (Figs. 5, 6), armed with 20 longitudinal rows of generally 13 (rarely 14) hooks each (Figs. 2, 7). In each row, 2 (rarely 3 ) posterior basal hooks without roots, shorter, narrower and less recurved than anterior ones. Total number of proboscis hooks 260, including 220 large hooks with roots and 40 rootless single hooks present at proboscis base. Differences between 

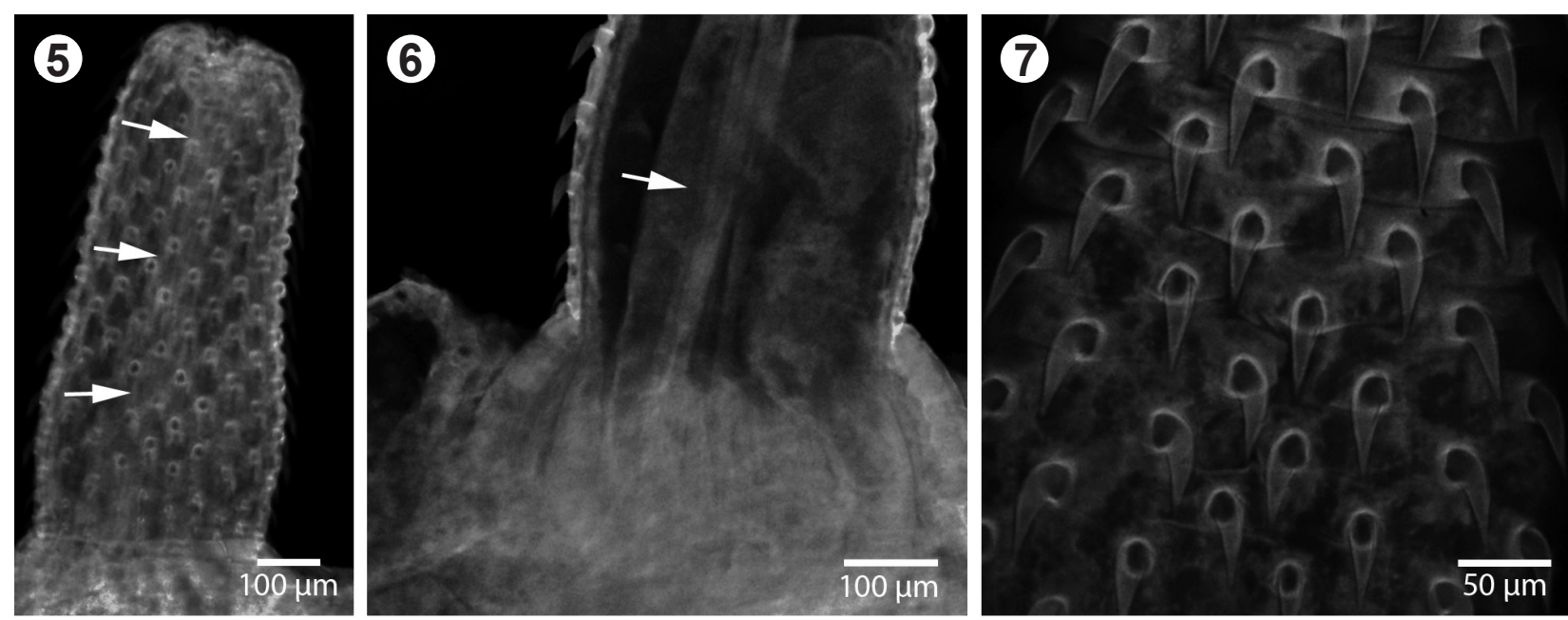

Figs. 5-7. Cystacanths of Corynosoma pseudohamanni Zdzitowiecki, 1984 from Trematomus bernacchii, Weddell Sea. Confocal laser scanning micrographs. Fig. 5. Proboscis with retractor muscles (arrows). Fig. 6. Cross section of basal part of proboscis with retractor muscles (arrow) and anterior part of trunk. Fig. 7. Frontal view of the middle part of proboscis showing pattern of distribution of hooks.
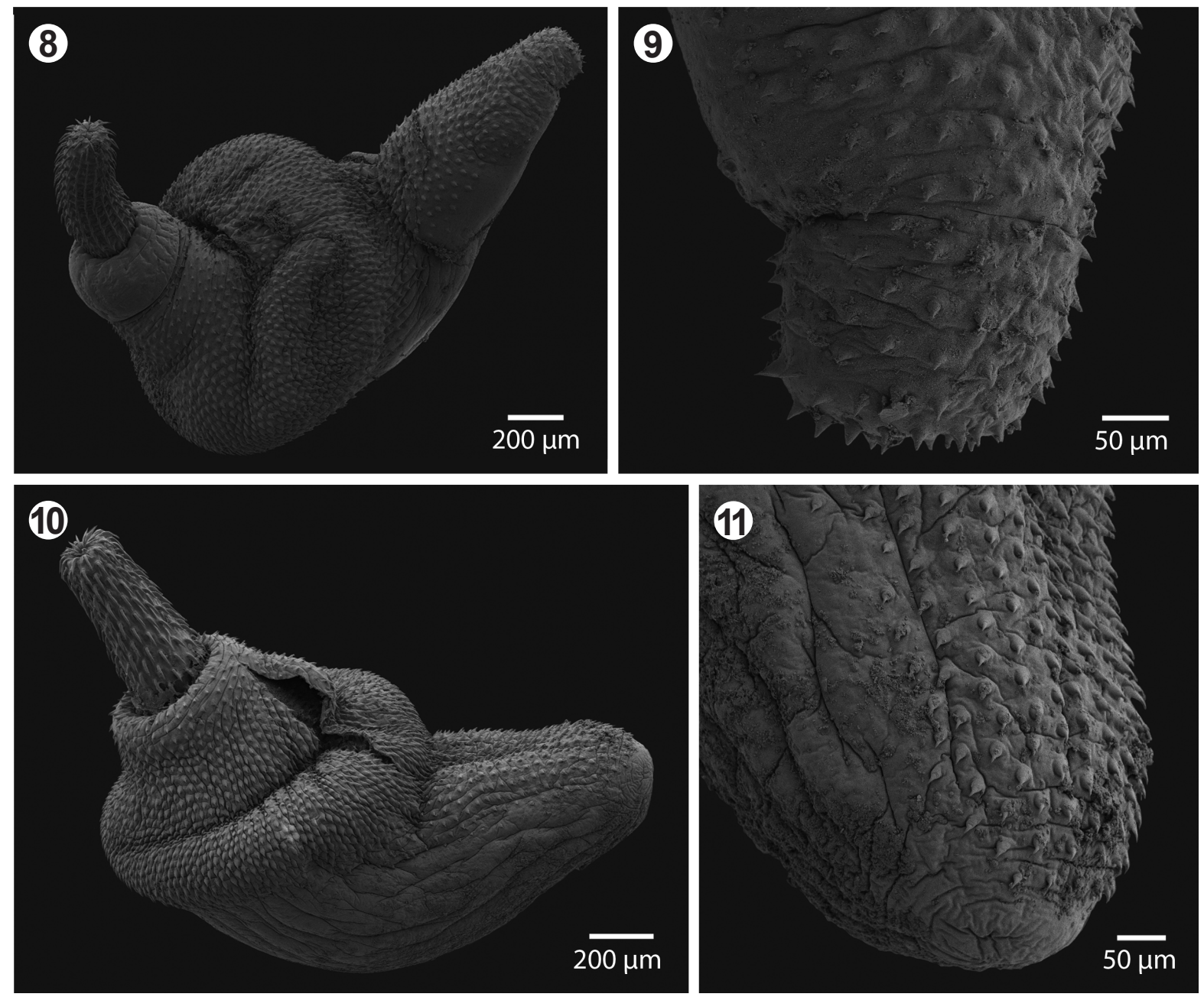

Figs. 8-11. Cystacanth of Corynosoma pseudohamanni Zdzitowiecki, 1984 from Trematomus bernacchii and Gobionotothen gibberifrons, Weddell Sea. Scanning electron micrographs. Fig. 8. Lateroventral view of male. Fig. 9. Detail of male posterior end with genital spines on both (ventral and dorsal) sides of the body. Fig. 10. Lateral view of female. Fig. 11. Detail of the posterior end of female with genital spines present only on the ventral side. 

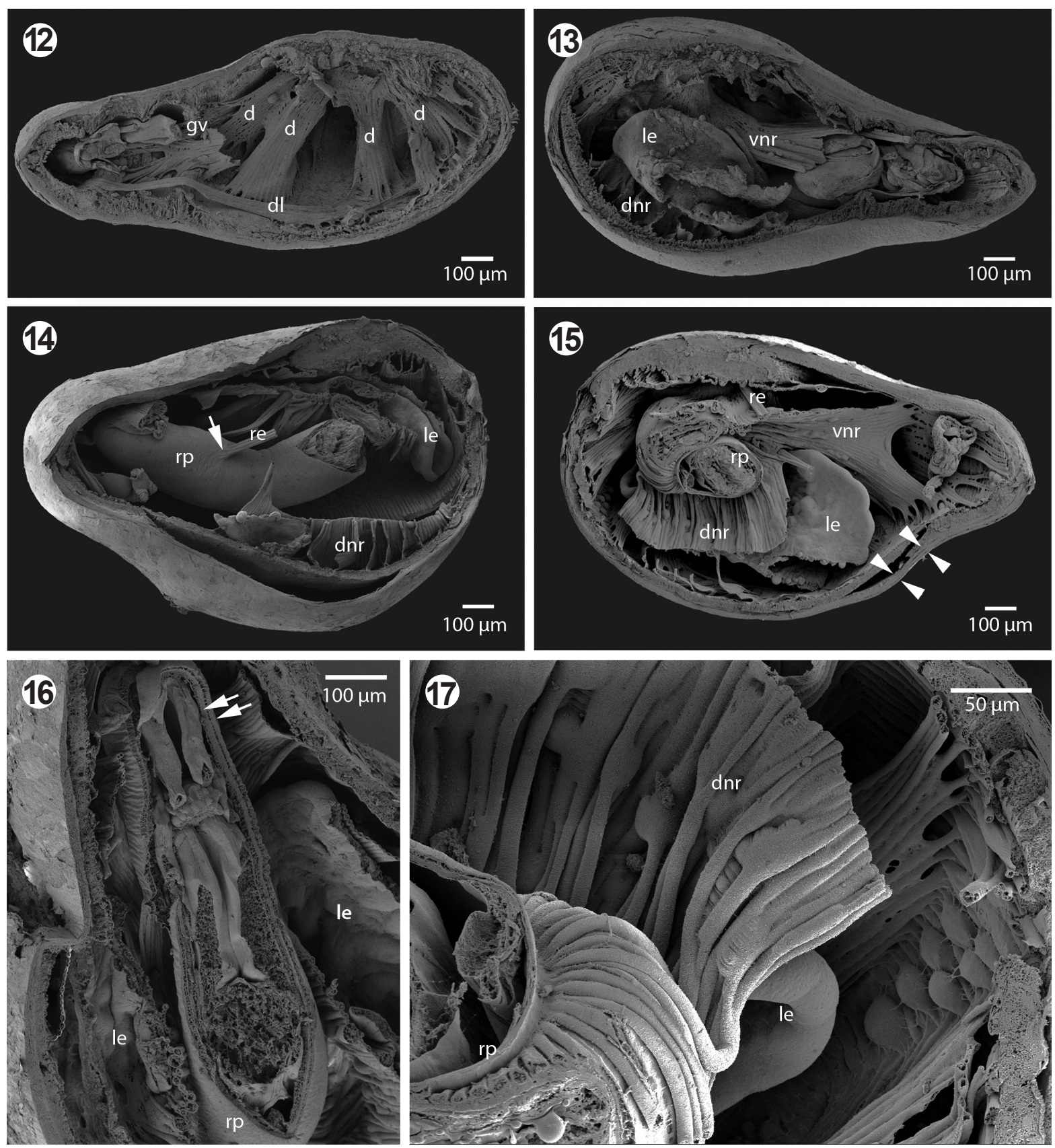

Figs. 12-17. Sagittal razor sections of cystacanths of Corynosoma pseudohamanni Zdzitowiecki, 1984 showing anatomical details from lateral view. Scanning electron micrographs. Fig. 12. Proboscis and most of internal organs removed. Fig. 13. Internal organs. Fig. 14. Cystacanth wit origin of the retinaculum (arrow). Fig. 15. Cystacanth covered with host tissue (arrowhead). Fig. 16. Detail of the receptacle of the proboscis. Arrows indicate double muscular wall. Fig. 17. Dorsal neck retractor connection to the base of the proboscis receptacle. Abbreviations: $\mathrm{d}$ - disk muscle; $\mathrm{dl}$ - dorsolateral muscle; $\mathrm{dnr}$ - dorsal neck retractor; gv - genital vestibule muscle; le - lemniscus; re - retinacular muscle; rp - receptacle of the proboscis; vnr - ventral neck retractor.

sexes not recorded. Third to fifth hooks from top being largest. Hooks in distal part of proboscis more slender, having thorns longer than roots. Towards proboscis base, root length increasing simultaneously with thickening of hooks. Roots of prebasal hooks usually longer than thorns.

Truncated-cone neck wider than longer, often retracted into foretrunk (Fig. 10). Proboscis receptacle doublewalled (Fig. 16). Body pyriform, foretrunk expanded in form of ellipsoidal swelling near junction with neck, bent ventrally to some extent, with dorsal surface more prominently inflated than ventral surface. Gradual attenuation of foretrunk leading to inconspicuously narrowed cone-shaped hindtrunk. Dilated foretrunk not separated from hindtrunk by constriction. Anteriormost foretrunk with four groups of specialized longitudinal disk muscles (Fig. 12) arranged as roughly semitubular bundles. 
Table 1. Measurements of hooks ( $\mu \mathrm{m})$ of Corynosoma pseudohamanni.

\begin{tabular}{|c|c|c|c|c|c|c|c|c|}
\hline \multirow[b]{3}{*}{ Hook No. } & \multicolumn{5}{|l|}{ Present study } & \multicolumn{3}{|c|}{ Zdzitowiecki (1984b) } \\
\hline & \multicolumn{5}{|c|}{ Males cystacanths } & \multicolumn{3}{|c|}{ Males $(n=2)$ - adults } \\
\hline & Thorn length & Base width & Root length & Blade curvature & $\mathrm{n}$ & Thorn length & Base width & Root length \\
\hline I & $53-62(59)$ & $14-16(15)$ & $37-58(47)$ & $55-75(65)$ & 3 & $62-74$ & $13-14$ & $55-60$ \\
\hline II & $59-69(64)$ & $14-19$ (16) & $48-56(50)$ & $65-82(74)$ & 3 & $68-75$ & $14-14$ & $56-64$ \\
\hline III & $64-70(67)$ & $17-19(18)$ & $49-66(59)$ & $75-80(78)$ & 4 & $72-73$ & $14-15$ & $57-64$ \\
\hline IV & $67-69(68)$ & $18-21(19)$ & $51-63(57)$ & $82-83(82)$ & 4 & $71-72$ & $16-17$ & $55-64$ \\
\hline V & $66-77(69)$ & 19-20 (19) & $46-71(59)$ & $79-89$ (82) & 5 & $71-71$ & $17-18$ & $59-64$ \\
\hline VI & $59-71(65)$ & $18-21(20)$ & $50-72(56)$ & $68-83(78)$ & 5 & $69-70$ & $17-18$ & $61-65$ \\
\hline VII & $59-69(63)$ & $19-23(21)$ & $51-70(58)$ & $69-85(76)$ & 5 & $65-68$ & $18-18$ & $61-65$ \\
\hline VIII & $58-68(62)$ & $19-23(21)$ & $51-69(58)$ & $64-82(74)$ & 5 & $63-65$ & 19-19 & $65-66$ \\
\hline IX & $54-63(58)$ & $18-21(20)$ & $52-77$ (59) & $63-76(71)$ & 5 & $58-63$ & $18-19$ & $63-65$ \\
\hline $\mathrm{X}$ & $54-63(58)$ & $17-22(19)$ & $52-64(57)$ & $66-76(72)$ & 5 & $56-58$ & $17-18$ & $60-63$ \\
\hline XI & $47-53(51)$ & $18-20(19)$ & $44-62(53)$ & $60-73(65)$ & 5 & $48-53$ & $11-17$ & $28-53$ \\
\hline XII & $39-46(43)$ & 9-12 (11) & - & $45-56(51)$ & 5 & $43-44$ & $11-11$ & $26-27$ \\
\hline \multirow[t]{2}{*}{ XIII } & $34-46(39)$ & $10-13(12)$ & - & $37-54(45)$ & 5 & 42 & 10 & 21 \\
\hline & \multicolumn{5}{|c|}{ Females cystacanths } & & & \\
\hline Hook No. & Thorn length & Base width & Root length & Blade curvature & $\mathrm{n}$ & & & \\
\hline I & $62-68(65)$ & $14-20(17)$ & $47-59(55)$ & 69-83 (76) & 3 & & & \\
\hline II & $70-72(71)$ & 17-21 (19) & $60-72(64)$ & $73-85$ (79) & 3 & & & \\
\hline III & $63-72(69)$ & $18-20(19)$ & $58-67(62)$ & $72-86(81)$ & 3 & & & \\
\hline IV & $62-76(69)$ & $17-22(20)$ & $64-71(67)$ & $70-90(82)$ & 5 & & & \\
\hline V & $59-76(69)$ & $17-24(21)$ & $56-75(62)$ & $72-92(82)$ & 6 & & & \\
\hline VI & $59-73(67)$ & $17-25(20)$ & $55-71(63)$ & $68-88(80)$ & 6 & & & \\
\hline VII & $58-72(66)$ & $16-26(21)$ & $56-67(61)$ & $65-87(78)$ & 6 & & & \\
\hline VIII & $53-66(61)$ & $14-22(19)$ & $53-64(59)$ & $56-84(73)$ & 6 & & & \\
\hline IX & $55-64(60)$ & $16-23(20)$ & 54-64 (59) & $61-78$ (71) & 6 & & & \\
\hline $\mathrm{X}$ & $51-59(56)$ & $16-21(19)$ & $46-61(56)$ & $56-74(67)$ & 6 & & & \\
\hline XI & $44-56(52)$ & 13-20 (18) & $42-60(52)$ & $47-70$ (60) & 6 & & & \\
\hline XII & $40-46(42)$ & $11-12$ (12) & - & $44-52(48)$ & 6 & & & \\
\hline XIII & $37-44(40)$ & 9-16 (11) & - & $37-52(44)$ & 6 & & & \\
\hline
\end{tabular}

Trunk spines asymmetrically distributed, entirely covering foretrunk and extending to ventral hindtrunk. Spines surrounding genital pore present, following anterior hindtrunk spines as continuous field; their range and distribution differ in both sexes (see Figs. 9 and 11). Lemnisci rounded, quite broad, leaf-shaped, not reaching level of proboscis receptacle. Dorsal neck retractor muscle divided into two fan-shaped bundles (Figs. 14, 15, 17), not associated with lemnisci. Each bundle fans out to attach itself along dorsal trunk. Single ventral neck retractor fans out and attaches itself to both sides of ventrolateral hindtrunk (Figs. 13, 15). Retinacula arising near middle of ventrolateral proboscis receptacle (Fig. 14). Genital vestibule muscles surround genital opening (Fig. 12), merged and soon separated towards anterior portion of body; each muscle continues as dorsolateral band (Fig. 12).

Males (based on five specimens from Trematomus bernacchi and Gobionotothen gibberifrons; $\mathrm{n}=5$, unless otherwise indicated; range with mean in parentheses): Total body length 2.9-3.6 mm (3.2 mm) (Figs. 3, 8). Trunk $2.0-2.7 \mathrm{~mm}(2.4 \mathrm{~mm})$ long. Foretrunk $1.1-1.6 \mathrm{~mm}(1.3 \mathrm{~mm})$ long, $1.3-1.6(1.5 \mathrm{~mm})$ wide; hindtrunk 853-1395 (997) long, 549-776 (651) wide.
Foretrunk evenly dispersed, spines 28-42 (36) long; spines in middle of trunk 24-41 (32) long. Armature extends ventrally to posterior end, mixing with genital spines 21-28 (25) long $(\mathrm{n}=50)$. Genital spines surrounding genital opening on ventral and dorsal side; 5-6 rows of patchy transversal spines present on dorsal side.

Proboscis 822-909 (867) long, 299-337 (325) wide, length/width ratio 2.4-2.8 (2.7) (Fig. 1). Two or rarely three rows of basal hooks without roots, 34-46 long, 9-13 wide $(\mathrm{n}=10)$. Anterior hooks of similar length and with simple roots, 47-77 long, 18-23 wide at junction with root (base) $(n=49)$ (Table 1). Neck 190-293 (237) long. Proboscis receptacle $1.1-1.3 \mathrm{~mm}(1.2 \mathrm{~mm})$ long, 241-400 (316) wide. Lemnisci 780-976 (888) long. Testes 102-227 (172) long $(n=9)$, subspherical, located obliquely at base of foretrunk or anteriorly in hindtrunk, near proboscis receptacle.

Females (based on six specimens from Trematomus bernacchi and Gobionotothen gibberifrons; $\mathrm{n}=6$, unless otherwise indicated; range with mean in parentheses): Total body length $2.3-3.2 \mathrm{~mm}(2.8 \mathrm{~mm})$ (Fig. 10). Trunk 1.8-2.4 mm (2.1 mm) long. Foretrunk 0.9-1.4 mm (1.1 mm) long, $0.9-1.9 \mathrm{~mm}(1.3 \mathrm{~mm})$ wide; hindtrunk 
473-1 100 (803) long, 378-705 (577) wide. Foretrunk covered with spines 31-44 (36) long; spines in middle of trunk 26-35 (30) long. Armature extends ventrally to posterior end, mixing with genital spines 23-29 (25) long $(n=60)$. Female armature ends ventrally, anterior to genital opening, spines never occur on dorsal side of body (Fig. 11).

Proboscis 699-916 (831) long, 262-327 (305) wide, length/width ratio $2.4-3.1$ (2.7). Two, rarely three rows of basal hooks without roots, 37-46 long, 9-16 wide $(\mathrm{n}=10)$. Anterior hooks of similar length and with simple roots, 44-76 long, 13-26 wide at junction with root (base) $(\mathrm{n}=68)$ (Table 1). Neck 154-254 (217) long. Proboscis receptacle 1.0-1.2 mm (1.1 mm) long, 224-355 (312) wide. Lemnisci 822-1007 (907) long. Only anlagen of female genital complex observed, but not measurable.

Hosts: Trematomus bernacchii Boulenger, Gobionotothen gibberifrons (Lönnberg) and Notothenia coriiceps Richardson (Perciformes, Nototheniidae).

Date of collection: February 2012.

Site of infection: Surface of the viscera and in the tissues of the mesentery in the abdominal cavity.

Prevalence and intensity: T. bernacchii: three fish infected/three fish examined; intensity 15-61 (mean 32) cystacanths; G. gibberifrons: 5/5; 3-66 (mean 31); N. coriiceps: $1 / 1 ; 144$.

Deposition of voucher material: Two specimens stored in vials with $70 \%$ ethanol deposited in the Helminthological Collection of the Institute of Parasitology, BC ASCR, in České Budějovice, Czech Republic (Cat. No. A-83), other unregistered specimens in the Department of Botany and Zoology.

\section{DISCUSSION}

Zdzitowiecki (1978) found juvenile acanthocephalans (cystacanths) in Notothenia rossii Richardson and seven other fish species from the South Shetland Islands and South Georgia. Cystacanths were determined as Corynosoma hamanni (Linstow, 1892) sensu lato with notification on species complex. In a later study (Zdzitowiecki 1984b), C. hamanni, the type host of which is Hydrurga leptonyx (Blainville), was redescribed based on adults from seals and cystacanths from paratenic hosts (fish) from the same region (South Shetland Island). In addition, Zdzitowiecki (1984b) described a new taxon, C. pseudohamanni, from Leptonychotes weddellii (Lesson), which is type and principal host of this species in both the Atlantic and Pacific sectors of Antarctica (Zdzitowiecki 1986, Stryukov 2004).

Zdzitowiecki (1984b) differentiated adults of C. pseudohamanni from those of $C$. hamanni by the following characteristics: smaller dimensions of the body and organs (proboscis length, length of proboscis hooks, embryophore), smaller number of hooks per row and usually smaller basal hooks and distribution of the genital arma- ture in females (the genital spines do not occur on the dorsal side of the body).

We emphasize the differentional weight of the mean value of the length of the measured parts of proboscis hooks. The cumulative mean (= the mean from mean values of individuals from the measured population samples) is always higher for adult males of $C$. hamanni. According to measurements of $C$. hamanni provided by Zdzitowiecki (1984b), the cumulative means for one hook from all values of a whole series of hooks (I-XI, i.e. those possessing roots) were $78.3 \mu \mathrm{m}$ for thorn length, $69.5 \mu \mathrm{m}$ for root length and $20.3 \mu \mathrm{m}$ for base width. For C. pseudohamanni these values were $65.9 \mu \mathrm{m}, 59.7 \mu \mathrm{m}$ and $16.4 \mu \mathrm{m}$, which differentiates both taxa.

Van Cleave (1952) and Petrochenko (1956) suggested that, in most acanthocephalan species, attachment structures are fully formed at the cystacanth stage. The number and arrangement of hooks on the proboscis and the extension of spines on the trunk are never modified in the definitive host (Van Cleave 1952, Hernández-Orts et al. 2012).

In cystacanths of Corynosoma species, the dimensions of the proboscis and the development and size of both proboscis hooks and trunk spines are usually identical with those of adults (Laskowski et al. 2008). According to Zdzitowiecki (1991, 2001) and Laskowski et al. (2010), C. pseudohamanni cystacanths were identified on the basis of proboscis length (shorter than $1 \mathrm{~mm}$ ), the number of basal hooks in a row (usually two, one or three in some rows), trunk shape and armature distribution (especially of the hindbody of females). The relaxed and everted cystacanths of $C$. pseudohamanni from our paratenic fish hosts clearly exhibit these features of attachment and fixing apparatus (Table 1).

Our values for the hook length and root length of cystacanths correspond to the values for adults provided by Zdzitowiecki (1984b). Base width appears to be a very stable feature as it does not change in the course of cystacanth development to the adult stage. We confirmed that along with other species of Corynosoma (see Petrochenko 1956), measurements of the hooks do not differ between males and females. For male and female (in parentheses) cystacanths of $C$. pseudohamanni, the cumulative means of the hook length, base width and root length were $62.2 \mu \mathrm{m}(64.1 \mu \mathrm{m}), 18.8 \mu \mathrm{m}(19.3 \mu \mathrm{m})$ and $59.7 \mu \mathrm{m}$ $(60.0 \mu \mathrm{m})$, respectively; the curvature of the thorn blade was $74.3 \mu \mathrm{m}(75.4 \mu \mathrm{m})$. For comparison, values of proboscis hook lengths for cystacanths found in the intermediate host Cheirimedon femoratus (Pfeffer) (Amphipoda) by Zdzitowiecki (2001) and Laskowski et al. (2010) are presented in Table 2.

Comparison of the length of the proboscis with that of the trunk and other organs indicates that the proboscis grows in cystacanth phase, in both the amphipod intermediate host and fish paratenic host (Zdzitowiecki and Presler 2001, Laskowski et al. 2010). In the definitive 
Mašová and Baruš: Cystacanths of Corynosoma pseudohamanni

Table 2. Selected measurements (in $\mu \mathrm{m}$ ) of cystacanths and adults of Corynosoma pseudohamanni (males and females).

\begin{tabular}{|c|c|c|c|c|c|c|}
\hline \multirow[b]{2}{*}{ Sex } & \multicolumn{2}{|c|}{ Intermediate host (Amphipoda) } & \multicolumn{2}{|l|}{ Paratenic host (fish) } & \multicolumn{2}{|c|}{ Definitive host (seals) } \\
\hline & $\begin{array}{l}\text { Males } \\
(\mathrm{n}=4)\end{array}$ & $\begin{array}{l}\text { Not mentioned } \\
(\mathrm{n}=20)\end{array}$ & $\begin{array}{l}\text { Males } \\
(\mathrm{n}=5)\end{array}$ & $\begin{array}{l}\text { Females } \\
(\mathrm{n}=6)\end{array}$ & $\begin{array}{l}\text { Males } \\
(\mathrm{n}=20)\end{array}$ & $\begin{array}{l}\text { Females } \\
(\mathrm{n}=20)\end{array}$ \\
\hline Trunk length (mm) & $1.1-1.4$ & $1.3-1.9$ & $2.0-2.7(2.4)$ & $1.8-2.4(2.1)$ & $3.5-4.9$ & $2.7-3.9$ \\
\hline Proboscis length & $640-720$ & $742-957$ & $821-910(867)$ & $699-916(831)$ & 799-929 & $804-1001(910)$ \\
\hline Proboscis width & - & Prebasal 286 & $299-336(324)$ & $262-327(307)$ & $258-325$ & $300-358(330)$ \\
\hline Hook (max. length) & About 70 & $63-67$ & $68-70(69)$ & $71-76(73)$ & $67-79(72)$ & $64-81(75)$ \\
\hline Neck length & - & - & 190-293 (237) & $154-254(217)$ & $300-420$ & $370-510$ \\
\hline $\begin{array}{l}\text { Proboscis receptacle } \\
\text { length }\end{array}$ & $840-950$ & - & $1125-1311(1230)$ & $1031-1234(1115)$ & $1190-1510$ & $1190-1560$ \\
\hline $\begin{array}{l}\text { Proboscis receptacle } \\
\text { width }\end{array}$ & $270-290$ & - & $241-400(316)$ & $224-355(312)$ & $310-440$ & $380-480$ \\
\hline Right testis & - & - & $102-227$ & - & $\begin{array}{l}540-850 \times \\
450-710\end{array}$ & - \\
\hline Left testis & - & - & $140-213$ & - & $\begin{array}{l}540-890 \times \\
390-650\end{array}$ & - \\
\hline Reference & $\begin{array}{l}\text { Zdzitowiecki } \\
(2001)\end{array}$ & $\begin{array}{l}\text { Laskowski et al. } \\
(2010)\end{array}$ & Present study & Present study & $\begin{array}{l}\text { Zdzitowiecki } \\
\text { (1984b) }\end{array}$ & $\begin{array}{l}\text { Zdzitowiecki } \\
\text { (1984b) }\end{array}$ \\
\hline
\end{tabular}

$\mathrm{n}=$ number of measurements; range and mean (in parentheses)

host (seals), it is almost fully developed (Table 2) (Zdzitowiecki 1984a,b). The distribution of genital spines, which shows sexual dimorphism, is also characteristic of C. pseudohamanni. For adults, Zdzitowiecki (1984b) reported a mean length of $52 \mu \mathrm{m}$ and a width of $13 \mu \mathrm{m}$ in the middle part of the trunk, for genital spines a mean length of $51 \mu \mathrm{m}$ and a width of $21 \mu \mathrm{m}$. He also noted that the genital spines are smaller than the somatic ones on the foretrunk. For immature females of $C$. pseudohamanni from seabirds, Dimitrova et al. (1996) reported the length of trunk spines on the anterior discoid part of the body to be $17-45 \mu \mathrm{m}$ (sometimes up to $50 \mu \mathrm{m}$ ), on the ventral surface $17-35 \mu \mathrm{m}$, and around the genital pore 17-34 $\mu \mathrm{m}$.

In the present study $(n=110)$, the following measurements of males were obtained (foretrunk spines vs genital spines): range $28-42 \mu \mathrm{m}$, mean $35.5 \mu \mathrm{m}$, vs $21-28 \mu \mathrm{m}$, mean $24.5 \mu \mathrm{m}$; for females: range 33-44 $\mu \mathrm{m}$, mean $36.5 \mu \mathrm{m}$, vs 23-29 $\mu \mathrm{m}$, mean $25 \mu \mathrm{m}$. This means that somatic spines in cystacanths are shorter and during the transition of specimens to the adult stage. However, the ratio of their length on the anterior and posterior parts of the trunk remains constant.

The ratio of the length of the hindtrunk and foretrunk is considered an important identification feature. Zdzitowiecki and Presler (2001) and Laskowski et al. (2010) emphasized that male cystacanths have a hindtrunk shorter than the foretrunk. Zdzitowiecki (1984b) expressed this ratio for adult males (foretrunk to the whole trunk length), to range from 56 to $69 \%$ (mean $60 \%$ ). This ratio in cystacanths measured in the present study was $49-64 \%$ (mean $59 \%$ ), which indicates taxonomic importance of this feature. According to Zdzitowiecki (1984b), the value ranges between $67-85 \%$ (mean $75 \%$ ) for adult females of C. pseudohamanni; in the present specimens, the range was $45-74 \%$ (mean $62 \%$ ).
The muscles of cystacanth of C. pseudohamanni were studied by SEM for the first time. We document that the dorsal neck retractor muscles are not associated with lemnisci, a single ventral neck retractor is present and the retinacula are attached to the proboscis receptacle; we also described genital vestibule muscles. Inner anatomy was quite similar to acanthocephalans described by Aznar et al (1999).

Acanthocephalans at the cystacanth stage usually have a wide range of paratenic hosts. According to Zdzitowiecki (1984b, 1986, 1990, 1996), Zdzitowiecki and Zadrożny (1999), Zdzitowiecki et al. (1999), Zdzitowiecki and Laskowski (2004), and Laskowski et al. (2012), C. pseudohamanni have been reported from 19 fish species: nine of the Nototheniidae, two of the Bathydraconidae, six of the Chaenichthyidae, and two of the Harpagiferidae. Our material includes specimens from three rockcod of the Nototheniidae: T. bernacchii, G. gibberifrons and N. coriiceps, which have already been reported as paratenic hosts by Zdzitowiecki (1984b). In contrast, Cheirimedon femoratus is the only known species of amphipod reported as an intermediate host (Zdzitowiecki 2001, Zdzitowiecki and Presler 2001, Laskowski et al. 2010).

Acknowledgements. The authors are grateful to the staff of the Czech Antarctic expedition 2011-2012 in the James Ross Island for their help and support. The authors also acknowledge unrestricted use of the facilities at the Czech Johann Gregor Mendel Antarctic Station. This study was supported by the Czech Science Foundation (project No. P505/12/G112), by the Department of Botany and Zoology, Faculty of Science, Masaryk University and by foundation 'Nadání Josefa, Marie a Zdenky Hlávkových'. Thanks also go to the staff at the Laboratory of Electron Microscopy, Institute of Parasitology, Biology Centre of the ASCR, České Budějovice for their technical assistance and to Eva Kašparová for help with fish identification. 
Appeltans W., Bouchet P., Boxshall G.A., De Broyer C., De Voogd N.J., Gordon D.P., Hoeksema B.W., Horton T., Kennedy M., Mees J., Poore G.C.B., Read G., Stöhr S., Walter T.C., Costello M.J. (Eds.) 2012: World Register of Marine Species. World Wide Web electronic publication, http:// www.marinespecies.org, version 08/2012.

Aznar F.J., Bush A.O., Fernández M., Raga J.A. 1999: Constructional morphology and mode of attachment of the trunk of Corynosoma cetaceum (Acanthocephala: Polymorphidae). J. Morphol. 241: 237-249.

Aznar F.J., Pérez-Ponce de León G., Raga. J.A. 2006: Status of Corynosoma (Acanthocephala: Polymorphidae) based on anatomical, ecological and phylogenetic evidence, with the erection of Pseudocorynosoma n. gen. J. Parasitol. 92: 548-564.

Dimitrova Z.M., Chipev N.H., Georgiev B.B. 1996: Record of Corynosoma pseudohamanni Zdzitowiecki, 1984 (Acanthocephala, Polymorphidae) in birds at Livingston Island, South Shetlands, with a review of Antarctic avian acanthocephalans. In V. Golemansky and N. Chipev (Eds.), Bulgarian Antarctic Research. Life Sciences, Vol. 1. Pensoft Publishers, Sofia and Moscow, pp. 102-110.

Froese R., Pauly D. (Eds.) 2012: FishBase. World Wide Web electronic publication. www.fishbase.org, version 06/2012

Hernández-Orts J.S., Timi J.T., Raga J.A., García-Varela M., Crespo E.A., Aznar F.J. 2012: Patterns of trunk spine growth in two congeneric species of acanthocephalan: investment in attachment may differ between sexes and species. Parasitology 139: 945-955.

Hoberg E.P. 1986: Aspects of ecology and biogeography of Acanthocephala in Antarctic seabirds. Ann. Parasitol. Hum. Comp. 61: 199-214.

Laskowski Z., JeŻewski W., Zdzitowiecki K. 2008: Cystacanths of Acanthocephala in notothenioid fish in the Beagle Channel (sub-Antarctica). Syst. Parasitol. 70: 107-117.

Laskowski Z., JeŻewski W., Zdzitowiecki K. 2010: New data on the occurrence of Acanthocephala in Antarctic Amphipoda. Acta Parasitol. 55: 161-166.

Laskowski Z., Korczak-Abshire M., Zdzitowiecki K. 2012: Changes in acanthocephalan infection of the Antarctic fish Notothenia coriiceps in Admiralty Bay, King George Island, over 29 years. Pol. Polar Res. 33: 99-108.

Moser M., Cowen R.K. 1991: The effects of periodic eutrophication on parasitism and stock identification of Trematomus bernacchii (Pisces: Nototheniidae) in McMurdo Sound, Antarctica. J. Parasitol. 77: 551-556.
Petrochenko V.I. 1956: [Acanthocephala of Domestic and Wild Animals.] Vol. 1. Izdatelstvo Akademii Nauk SSSR, Moscow, 435 pp. (In Russian.)

STRYuKov A.A. 2004: [Invasion of Antarctic phocid seals by acanthocephalans.] Vestn. Zool. 38: 23-29. (In Russian.)

Van Cleave. H.J. 1952: Some host-parasite relationships of the Acanthocephala, with special reference to the organs of attachment. Exp. Parasitol. 1: 305-330.

ZDZitowiecki K. 1978: On the occurrence of juvenile acanthocephalans of the genus Corynosoma Lühe, 1904 in fishes off South Georgia and South Shetland Island (the Antarctic). Acta Ichthyol. Piscat. 8: 111-127.

Zdzitowiecki K. 1984a: Some Antarctic acanthocephalans of the genus Corynosoma parasitizing Pinnipedia, with descriptions of three new species. Acta Parasitol. Pol. 29: 359-377.

ZDZITOWIECKI K. 1984b: Redescription of Corynosoma hamanni (Linstow, 1892) and description of C. pseudohamanni sp. n. (Acanthocephala) from the environs of the South Shetlands (Antarctic). Acta Parasitol. Pol. 29: 379-393.

Zdzitowiecki K. 1986: Acanthocephala of the Antarctic. Pol. Polar Res. 7: 79-117.

ZDZitowiecki K. 1990: Occurrence of acanthocephalans in fishes of the open sea off the South Shetlands and South Georgia (Antarctic). Acta Parasitol. Pol. 35: 131-142.

Zdzitowiecki K. 1991: Antarctic Acanthocephala. In: J.W. Wägele and J. Sieg (Eds.), Synopses of the Antarctic Benthos. Vol. 3. Koeltz Scientific Books, Königstein, 116 pp.

Zdzitowiecki K. 1996. Acanthocephala in fish in the Weddell Sea (Antarctic). Acta Parasitol. 41: 199-203.

ZDZitowiecki K. 2001: Acanthocephala occurring in intermediate hosts, amphipods, in Admiralty Bay (South Shetland Islands, Antarctica). Acta Parasitol. 46: 202-207.

Zdzitowiecki K., Laskowski Z. 2004: Helminths of an Antarctic fish, Notothenia coriiceps, from the Vernadsky Station (Western Antarctica) in comparison with Admiralty Bay (South Shetland Islands). Helminthologia 41: 201-207.

Zdzitowiecki K., Palladino S., Vacchi M. 1999: Acanthocephala found in fishes in the Terra Nova Bay (Ross Sea, Antarctica). Pol. Polar Res. 20: 59-63.

Zdzitowiecki K., Presler P. 2001: Occurrence of Acanthocephala in intermediate hosts, Amphipoda, in Admiralty Bay, South Shetland Islands, Antarctica. Pol. Polar Res. 22: 205-212.

Zdzitowiecki K., Zadrożny T. 1999: Endoparasitic worms of Harpagifer antarcticus Nybelin, 1947 off the South Shetland Islands (Antarctic). Acta Parasitol. 44: 125-130. 